\title{
The Effect of Learning Model and Mathematical Ability into Student's Learning Outcomes in Evaluation Course of Chemistry Education State University of Medan
}

\author{
Gulmah Sugiharti* \\ Education Technology Doctoral Program, Postgraduate \\ Universitas Negeri Medan \\ Medan, Indonesia \\ Department of Chemistry Education \\ Universitas Negeri Medan \\ Medan, Indonesia, \\ *Corresponding authors : gulmahsugiharti@yahoo.com
}

\author{
Abdul Hamid K \\ Department of Building Engineering, Faculty of Engeneering \\ Universitas Negeri Medan \\ Medan, Indonesia
}

\section{Mukhtar}

Department of Mathematic, Faculty of Mathematics and Natural Science

Universitas Negeri Medan

Medan, Indonesia

\begin{abstract}
This quasi experimental study aims to investigate effect of Problem-based learning model and mathematical ability into student's learning outcome in Evaluation Course of Chemistry Education. About 2 classes of chemical education students in 2015 were involved in this study as total sample. They were taught by implementing problem Based Learning (PBL) and Direct Instruction (DI) model. This research is experimental research with factorial design $2 \times 2$. Data of student learning and mathematical ability were obtained by administering achievement test and mathematical ability test then were analyzed by using Analysis of Variance (ANOVA) two way (2x2) with significance level 0.05 . The sample groups in this study have met the criteria of homogeneity and normality test. The results of this study showed: (1) PBL model gives better learning result $(26.57 \pm 5.81)$ than DI model $(24.04 \pm 2.86)$; (2) students with high mathematical ability gained higher average learning outcomes $(26.08 \pm 4.23)$ rather than those with lower math skills $(24.53 \pm$ 2.97); And (3) there is an interaction between the PBL model and the mathematical ability. This study concludes that students with high mathematical ability are suitable to be taught by PBL model while students with low mathematical ability with DI model.
\end{abstract}

Keywords: learning outcomes, mathematical abiility, PBL, DI

\section{INTRODUCTION}

There are several important components that affect the success of learning such as learning model. Models of learning are monotonous and unidirectional still dominate the course of the course evaluation lecture.

Lecturers tend to give as much information as possible, while passive students. Situations like this are inevitable. Sometimes the lecturers are so enthusiastic but the students are not enthusiastic, just accept to whatever is taught. Untrained students disclose their ideas and can't find one topic of relevance with each other. Consequently, it can lead to the assumption that learning in the course of education, especially the Evaluation course, is considered difficult.

The real result in education is actually the process of thinking gained through learning as a discipline. Furthermore, to be able to keep up with the rapidly changing current students not only need to have process skills, but also need to have the ability to solve problems to cope with rapid technological change at this time. The use of learning models is an aspect that needs to gain emphasis in learning. 
Evaluation course is one of the interesting subjects to be studied because it covers aspects of daily life in measuring and assessing. Evaluation work is always done by teachers and prospective teachers as students. This can be seen from the development of researches on Evaluation that can facilitate or alleviate the work / activity of educators can even help the problems that occur in the field of education such as, value processing, problem-making, validation and so forth.

One of the learning models that can be used in delivering Evaluation course is the Problem-Based Learning model (PBL) $n$ Direct Instruction (DI) commonly used. PBL is a student-centered learning that empowers students to apply knowledge and skills to develop the best solution or problem solving [1] .

In addition to the learning model, there is another factor that is not less important in the lecture of students' mathematical ability, this is because the ability of mathematics is needed in studying the evaluation course, especially on the material analysis instrument. Mathematical ability can practice thinking and reasoning in drawing conclusions, for example through investigation, exploration, experimentation, showing similarity, difference, consistency and inconsistency [2].

Mathematical ability is an internal capability associated with addition, reduction, multiplication and comparison operations[3]. Oyedeji [4] say that mathematical ability to build multifaceted that reflects the ability to do quantitative or more specialized thinking Find, evaluate and manipulate relationships. Kovas et al [5] divides the mathematical ability into three categories: the ability of numbers used in solving the problem of calculation (Understanding number), the ability to understand the process of mathematics (Non-numerical process), the ability to perform simple calculations by using facts and terms ( Computation and Knowledge).

Mathematical ability to be one of the benchmarks of highorder thinking (high order thinking skills). The ability to solve mathematical problems is directly proportional to his mathematical abilities. Students with high mathematical thinking skills will be able to find high-resolution solutions. The unique mathematical ability to solve mathematical problems is also related to students' reasoning abilities. Supryanto's [6] results show that differences in reasoning ability affect a person's ability to solve math problems. Kusnadi et al [7] showed that the mathematical ability to differentiate students' cognitive learning achievement.

\section{RESEARCH METHODOLOGY}

This experimental research have been conducted on 2015 into 2 classes of chemistry education students at State University of Medan, taken purposively. By using 2 x 2 factorial design, there are two factors studied: Learning Model (A) and Mathematical Capability (B). Factor A involved 2 levels of learning model PBL (Problem Based Learning), and DI learning model (Direct Instruction). While factor B involved 2 levels of high mathematical ability and low mathematical ability. Data were collected by using achievement test and mathematics ability test. Data obtained were tested requirements with the test of normality (Liliefors test) and homogeneity (Bartlett test). Statistical test used descriptive and inferential statistics, then analyzed by using Analysis of Variance (ANOVA) two way (2x2) with significance level 0,05 . Use of data analysis technique refers to the research design used, namely $2 \times 2$ factorial design.

\section{RESEARCH RESULT AND DISCUSSION}

Overall the data obtained from the results of learning subjects Evaluation of students who have high and low mathematical skills are taught using PBL learning model and DI learning model, it was found that the score of learning outcomes course Student evaluation of 52 respondents showed an average of 25.30 with standard deviation 3 , 49. The highest score obtained by students is 34 and the lowest score 18. While the mode is at a score of 27.63 and the median is at a score of 28.65. The summary of research data is presented in table 1 below:

TABLE 1. SUMMARY OF RESEARCH DATA

\begin{tabular}{|c|c|c|c|c|}
\hline \multicolumn{2}{|c|}{ Variable } & \multicolumn{2}{|c|}{ Learning Method } & \multirow{2}{*}{ Total } \\
\cline { 3 - 5 } & PBL & $\begin{array}{c}\text { Direct } \\
\text { (DI) }\end{array}$ & \\
\hline \multirow{4}{*}{$\begin{array}{c}\text { Mathematic } \\
\text { Ability }\end{array}$} & \multirow{3}{*}{ High } & $\mathrm{n}=13$ & $\mathrm{n}=13$ & $\mathrm{n}=26$ \\
\cline { 3 - 5 } & \multirow{3}{*}{ Low } & $\mathrm{X}=29,61$ & $\mathrm{X}=22,54$ & $\mathrm{X}=26,08$ \\
\cline { 3 - 5 } & $\mathrm{s}=2,29$ & $\mathrm{~s}=2,22$ & $\mathrm{~s}=4,23$ \\
\hline & $\mathrm{n}=13$ & $\mathrm{n}=13$ & $\mathrm{n}=26$ \\
\cline { 3 - 5 } & $\bar{X}=23,53$ & $\bar{X}=25,54$ & $\bar{X}=24,53$ \\
\cline { 3 - 5 } & $\mathrm{s}=2,22$ & $\mathrm{~s}=2,22$ & $\mathrm{~s}=2,97$ \\
\hline \multirow{2}{*}{ Total } & $\mathrm{n}=26$ & $\mathrm{n}=26$ & $\mathrm{n}=26$ \\
\cline { 3 - 5 } & $\bar{X}=26,57$ & $\bar{X}=24,04$ & $\bar{X}=25,31$ \\
\cline { 3 - 5 } & $\mathrm{s}=5,81$ & $\mathrm{~s}=2,86$ & $\mathrm{~s}=3,49$ \\
\hline
\end{tabular}

The result of analyzed data obtained Anova calculations as presented on table 2 as follows.

TABLE 2. ANOVA CALCULATION RESULT

\begin{tabular}{|c|c|c|c|c|c|c|}
\hline \multirow[b]{2}{*}{$\begin{array}{l}\text { Source of } \\
\text { Variance }\end{array}$} & \multirow[b]{2}{*}{$\begin{array}{l}\text { Sum of } \\
\text { Square } \\
\text { Jumlah } \\
\text { Kuadrat } \\
\text { (JK) }\end{array}$} & \multirow[b]{2}{*}{$\begin{array}{l}\mathbf{D} \\
\mathbf{k}\end{array}$} & \multirow[b]{2}{*}{ 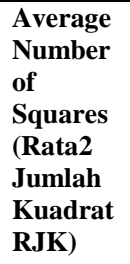 } & \multirow[b]{2}{*}{$\mathbf{F}_{\text {Hitung }}$} & \multicolumn{2}{|c|}{$\mathbf{F}_{\text {Tabel }}$} \\
\hline & & & & & $\begin{array}{l}\alpha=0,0 \\
5\end{array}$ & $\begin{array}{l}\alpha=0 \\
, 01\end{array}$ \\
\hline \multirow{3}{*}{$\begin{array}{l}\text { Between } \\
\text { Coloumn } \\
\text { (A) } \\
\text { Between } \\
\text { Row (B) } \\
\text { Interaction } \\
\text { (AxB) } \\
\end{array}$} & 83,77 & 1 & 83,77 & 16,69 & 4,05 & 7,20 \\
\hline & 30,77 & 1 & 30,77 & 6,13 & 4,05 & 7,20 \\
\hline & 267,77 & 1 & 267,77 & 53,34 & 4,05 & 7,20 \\
\hline In Group & 240,77 & $\begin{array}{l}4 \\
8 \\
\end{array}$ & 5,02 & & & \\
\hline Total & 623,08 & $\begin{array}{l}5 \\
1 \\
\end{array}$ & - & & & \\
\hline
\end{tabular}

The result of descriptive statistic table 1 . It is found that the average of the students 'learning achievement in the students' group evaluation is PBL 26.57, and the model group is DI 24.04. It was concluded that student's learning outcomes 
of Evaluation Courses taught using the PBL model are better than those taught using the DI model.

Based on the findings stated that in general the difference between PBL model and direct learning model lies in various aspects, among others, that direct learning shows the characteristics of learning that expects teachers to provide a book material (reading material) as a source of information, whereas in the model of learning PBL, students find more information through the approaches and strategies that lecturers apply. Learning using the DI model and PBL model is considered to be able to develop a model of learning that is able to foster students toward scientific thinking, only by using a more centralized DI model emphasis on learning materials, while the PBL model provide flexibility for students to review the material. Others related to the business of students to improve their ability to handle the problems that occur in everyday life in the community

Implementing PBL allows students to improve critical thinking skills, analyze and solve problems [8]. Surif, J, et al [9] says that group learning activities and leadership roles in PBLs help develop communication and collaboration of students' abilities. While Zejnilagic-Hajric, et al [10] mentioned that PBL improves student learning outcomes by promoting their skills and abilities in applying knowledge and problem solving, practicing high-level thinking and directing their own learning.

The result of descriptive statistical calculation table 2 . it is found that the average of the students' learning achievement of students who have high mathematical ability 26.08, and students who have low mathematical ability 24.53 and obtained $\mathrm{F}_{\text {count }}=6.13$ and $\mathrm{F}_{\text {tabel }}(1-52)=4.05$ at the 0.05 significance level, it means that $F_{\text {count }}>F_{\text {table. }}$. This shows that the average calculated learning result of the students' Evaluation Course which has high mathematical ability is higher than the student learning result which has low mathematical ability. Mastery over mathematical ability is very influential on the ability of students in developing the material being studied.

Mastery of mathematical concepts helps students in analyzing possible errors in new knowledge discovery. Thus for students who have high mathematical ability of learning to understand a concept will be better and students will be easier to learn a concept with a given concept or principle first. Given such basic knowledge, students will be able to draw conclusions more easily about what is learned. After that, students can apply the concepts or principles in solving the problems faced both in the learning activities and in the life of the community directly.

Adigwe's [11] study showed a positive correlation between mathematical ability and student achievement. In line with it Merdekawati [12] showed a significant difference in chemistry learning achievement between students with high and low mathematical ability. While Amalia [13] found that the average value of cognitive and affective achievement of students who have high mathematical ability is higher than students who have low mathematical ability.
Average Achievement of Learning Achievement Course of Student Evaluation of model group PBL 26,57 and group of direct learning model 24,04 and acquisition of average student learning result count group with high mathematical ability 26,08 and group having low mathematical ability $24,53$. From the calculation with the table Anova as in Table 1. obtained $F_{\text {count }} 53.34$ and $F_{\text {tabel }}$ (1-52) 7.20 at a significant level of 0.01 , this means that $\mathrm{F}_{\text {count }}>\mathrm{F}_{\text {table. Thus there is an }}$ interaction between the learning model with the mathematical ability of students in influencing the learning outcomes of the course of student evaluation.

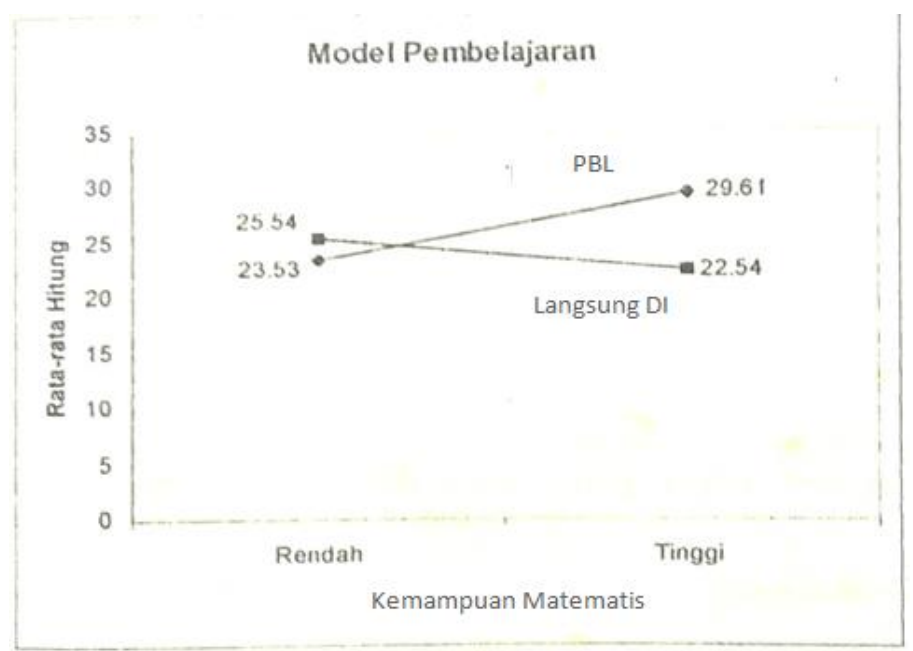

Fig.1. Interaction Between Mathematical Ability And Learning Model

\section{CONCLUSION}

The PBL model provides better learning outcomes in Evaluation Course when compared to the DI learning model.

Groups of students who have high mathematical ability obtain better learning outcomes course of Evaluation the results when compared with groups of students who have low mathematical ability.

There is an interaction between learning model with mathematical ability in influencing learning outcomes. Student evaluation on PBL model and DI model, from the result of research indicates that group of students who have high mathematical ability got score of learning outcomes course of Evaluation better taught by PBL model, while the student who have low mathematical ability obtain score of learning outcomes Course of Evaluation is better taught by DI model.

Based on the research presented in the research conclusion, that the PBL model is superior compared to the DI model, therefore it is expected that lecturers know and trained the PBL model and understand the mathematical ability and the condition of the students in learning so that the students are able to find and develop their own facts, concepts, procedures and principles and can foster and develop the behaviors, attitudes and values demanded. 


\section{REFERENCES}

[1] J. R., Savery, "Overview Of Problem-based Leraning: Definitions and Distinctions", Intedisciplinary Journal of Problam-Based Learning, vol 1 (1), pp 9-20, 2006.

[2] M. Kusumaningrum, dan A. A. Saefudin, "Mengoptimalkan Kemampuan Berpikir Matematika Melalui Pemecahan Masalah Matematika", Prosiding, (1-10). Program Studi Pendidikan Matematika FKIP Universitas PGRI Yogyakarta, 2012.

[3] D. S. R., Fatonah, Ashadi, dan Haryono, "Studi Komparasi Pembelajaran Kimia Menggunakan Model Inquiry Based Learning (IBL) Dan Problem Based Learning (PBL) Pada Materi Remokimia Kelas XI SMA N 1 Sukoharjo Dengan Memperhatikan Kemampuan Matematik Tahun Pelajaran 2015/2016", Jurnal Pendidikan Kimia (JPK), vol 5 (2), pp- 554-567, 2016

[4] S. O. Oyedeji, "Mathematics Skills As Predictors Of Science Achivement In Junior Secondary Schools", World J Young Researchers, vol 1(4). pp 60-65, 2011.

[5] Y. Kovas, C. Haworth, S. Petroll, and R. Plomin, "Mathematical ability Pf 10-Year-Old Boys And Girls: Genetic And Environmental Etiology Of Typical And Low Perfomance", J Learn Disabil, vol 40(6), National Institutes Of Health, America,pp. 554-567, 2007.

[6] A. Supryanto, Mardiyana, dan S. Subanti, , "Karakteristik Berpikir Matematis Siswa SMP Majelis Tafsir Al-Qur'an (Mta) Gemolong Dalam Memecahkan Masalah Matematika Pada Materi Sistem Persamaan Linear Dua Variabel (Spldv) Ditinjau Dari Kemampuan Penalaran Siswa Dan Gender", Jurnal Elektronik Pembelajaran Matematika, vol. 2(10),pp. 1056-1068, , 2014
[7] M. Kusnadi, S. Masykuri, Muyani, "Pembelajaran Kimia Dengan Problem Based Learning (PBL) Menggunakan Laboratorium Real Dan Virtual Ditinjau Dari Kemampuan Matematik Dan Kemampuan Berpikir Abstrak Siswa", Jurnal Inkuiri, vol 2(2), pp. 163-172, 2013.

[8] B. Akcay, "Problem-Based Learning in Science Education", Journal Turkish Science Education, vol.6(1), pp 26-36, 2009.

[9] J. Surif, N.H. Ibrahim, and M. Mokhtar, "Implementation of Problem Based Learning in Higher Education Institutions and Its Impact on Students Learning", Journal The 4th International research Symposium on Problem-Based Learning (IRSPBL), Malaysia, vol. -, pp. 66-73, 2013.

[10] M. Zejnilagic-Hajric, A. Sabeta, and I. Nuic, "The effects of Problembased learning on students' achievements in primary school chemistry", Bulletin of the Chemists and Technologis of Bosnia and Herzegovina, vol.44 pp.17-22. 2015

[11] J.C. Adigwe, "Effects Of Mathematical Reasoning Skills On Students' Achievement In Chemical Stoichiometry", Review of Education Institue of education Journal, University Of Nigeria Nsukka, Nigeria, vol. 23(1), pp 1-22, 2011.

[12] K. Merdekawati, "Pemgaruh Kemampuan Matematik Terhadap Prestasi Belajar Kimia", Jurnal Inovasi Dan Kewirausahaan, Yogyakarta, vol.2(1),pp. 26-31. 2013

[13] A. Ratna, S. Saputro and Ashadi, "Pengaruh Model Pembelajaran TAI Dan STAD Terhadap Pestasi Siswa Dengan Memperhatikan Kemampuan Awal Dan Kemampuan Matematik", Jurnal Inkuiri, Surakarta,vol.3(2), pp., 86-96, 2014. 
